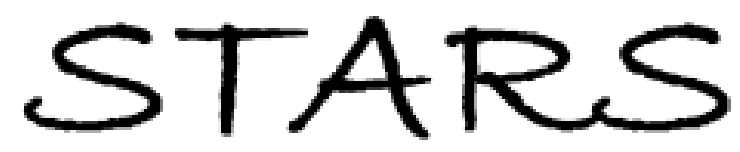

University of Central Florida

STARS

$1-1-2012$

\title{
Evaluating interannual water storage changes at watersheds in Illinois based on long-term soil moisture and groundwater level data
}

Dingbao Wang

University of Central Florida

Find similar works at: https://stars.library.ucf.edu/facultybib2010

University of Central Florida Libraries http://library.ucf.edu

This Article is brought to you for free and open access by the Faculty Bibliography at STARS. It has been accepted for inclusion in Faculty Bibliography 2010 s by an authorized administrator of STARS. For more information, please contact STARS@ucf.edu.

\section{Recommended Citation}

Wang, Dingbao, "Evaluating interannual water storage changes at watersheds in Illinois based on longterm soil moisture and groundwater level data" (2012). Faculty Bibliography 2010s. 3456.

https://stars.library.ucf.edu/facultybib2010/3456

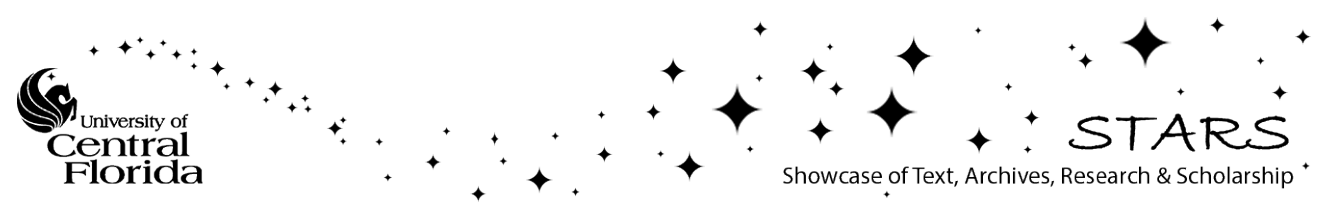




\title{
Evaluating interannual water storage changes at watersheds in Illinois based on long-term soil moisture and groundwater level data
}

\author{
Dingbao Wang ${ }^{1}$ \\ Received 5 April 2011; revised 4 January 2012; accepted 27 January 2012; published 1 March 2012.
}

[1] The annual water storage changes at 12 watersheds in Illinois are estimated based on the long-term soil moisture and groundwater level observations during 1981-2003. Storage change is usually ignored in mean annual and interannual water balance calculations. However, the interannual variability of storage change can be an important component in annual water balance during dry or wet years. Annual precipitation anomaly is partitioned into annual runoff anomaly, annual evaporation anomaly, and annual storage change. The estimated annual storage change ratios vary from $-60 \%$ to $40 \%$ at the study watersheds. The interannual variability of evaporation is not strongly correlated with the interannual variability of precipitation, but is correlated with the interannual variations of effective precipitation. As a response to the interannual variability of precipitation, the interannual variation of evaporation is smaller than those of runoff and storage change. The effect of annual water storage change increases the correlation coefficients between annual evaporation ratio and climate dryness index. Therefore, interannual water storage changes need to be included in the estimation of evaporation and total water supply in the Budyko framework. Effective precipitation can be used as a substitute for precipitation when computing evaporation ratio and climate dryness index.

Citation: Wang, D. (2012), Evaluating interannual water storage changes at watersheds in Illinois based on long-term soil moisture and groundwater level data, Water Resour. Res., 48, W03502, doi:10.1029/2011WR010759.

\section{Introduction}

[2] Long-term mean annual water balance at the watershed scale has been a fundamental research question in hydrological science:

$$
P=E+Q+\Delta S
$$

where $P, E$, and $Q$ are mean annual precipitation, evaporation, and runoff, respectively; $\Delta S$ is the mean annual change of water storage. Budyko [1958] postulated that the partitioning of $P$, to first order, was determined by the competition between available water $(P)$ and available energy measured by potential evaporation $\left(E_{p}\right)$. On the basis of data sets from a large number of watersheds and the work of Schreiber [1904] and Ol'dekop [1911], Budyko [1974] developed a relationship between evaporation ratio $(E / P)$ and climate dryness index $\left(E_{p} / P\right)$. In the literature, other functional forms of Budyko-type curves have been developed for the long-term water balance [e.g., Pike, 1964; Fu, 1981; Choudhury, 1999; Zhang et al., 2001; Porporato et al., 2004; Yang et al., 2008; Gerrits et al., 2009].

\footnotetext{
${ }^{1}$ Department of Civil, Environmental, and Construction Engineering, University of Central Florida, Orlando, Florida, USA.

Copyright 2012 by the American Geophysical Union 0043-1397/12/2011WR010759
}

[3] Besides the climate dryness index, the effects of other variables on the mean annual water balance have been studied to explain the observed deviation from the Budyko curve, e.g., the competing effects of climate fluctuations and watershed storage capacity [Milly, 1994a, 1994b], rainfall seasonality and soil moisture capacity [Sankarasubramanian and Vogel, 2002; Potter et al., 2005; Hickel and Zhang, 2006; Zhang et al., 2008], the relative infiltration capacity, relative soil water storage, and the watershed average slope [Yang et al., 2007], climate seasonality, soil properties and topography [Yokoo et al., 2008], vegetation type [Zhang et al., 2001; Oudin et al., 2008], vegetation dynamics [Donohue et al., 2007, 2010], and human activities [Wang and Hejazi, 2011].

[4] Recently, water balance estimates at finer temporal scales have been studied, especially the interannual variability of precipitation partitioning. The Budyko-type functions have been extended to study the relationship between the annual evaporation ratio and annual climate dryness index [Yang et al., 2007, 2009; Zhang et al., 2008]. Potter and Zhang [2009] tested the relationship with six functional forms of Budyko-type curves and one linear model, and found that rainfall seasonality was important in determining the functional forms. Jothityangkoon and Sivapalan [2009] examined the effects of intra-annual variability of rainfall (e.g., storminess and seasonality) on the interannual variability of the annual water balance through the simulation of annual runoff in three semiarid watersheds in Australia and New Zealand. 
[5] Similar to equation (1), the water balance at the annual scale is

$$
P_{i}=E_{i}+Q_{i}+\Delta S_{i}
$$

where $P_{i}, E_{i}$, and $Q_{i}$ are annual precipitation, evaporation, and runoff at year $i$, respectively; $\Delta S_{i}$ is the annual water storage change at the watershed scale. The effects of water storage change on annual water balance have been considered in several studies. Pike's [1964] functional form was based on the interannual variability of water balance for four watersheds in Malawi. The annual changes in groundwater storage were accounted for by constructing depletion curves under which the area was integrated to obtain a relationship between flow and storage left in the watershed at the end of the dry season. The annual storage change is negligible compared with precipitation and runoff in the four watersheds (Table 1 in the work of Pike [1964]). Zhang et al. [2008] found that Fu's equation, one functional form of Budyko-type curves, performed poorly on estimating annual streamflow in some watersheds in Australia, and they explained that it might be because of the impact of watershed water storage, which could not be neglected at the annual scale. Donohue et al. [2010] studied the annual water balance at 221 watersheds in Australia and found that the effect of nonsteady state conditions was an important source of variation at the annual scale and needed to be accounted for. During multiyear droughts, the annual storage change in the Murray Darling Basin can be up to twice the annual streamflow [Leblanc et al., 2009]. Flerchinger and Cooley [2000] studied the water balance of the Upper Sheep Creek watershed, a 26-ha semiarid mountainous sub-basin within the Reynolds Creek experimental watershed in southwest Idaho, United States. During 1985-1994, the minimum and maximum ratios of annual storage change (including soil moisture and groundwater) to annual precipitation were -0.45 and 0.2 , respectively, with the average absolute value of the ratios over the $10 \mathrm{yr}$ being 0.16 . The average ratio of annual runoff to annual precipitation (i.e., runoff coefficient) was found to be 0.05 . Thus, the annual storage carryover is significant in this watershed. Milly and Dunne [2002] accounted for the interannual storage change in the analysis of discharge variations for 175 large basins worldwide with a median area of $51,000 \mathrm{~km}^{2}$, and found that the annual storage change effect was important in some basins. Wang et al. [2009] found that the base flow-dominated basins in Nebraska Sand Hills exhibited a negative relationship between $\left(P_{i}-Q_{i}\right) / P_{i}$ and $E_{p i} / P_{i}$ when ignoring $\Delta S_{i}$, and that the interannual water storage change was not negligible because of the slow response of the base flow to the interannual change in precipitation.

[6] Therefore, the carryover of water storage, through interactions with seasonally varying climate inputs, will have an impact on the amount of runoff produced within the year, and hence mean annual water balance and the inter- and intra-annual variability of runoff yield and water balance [Zhang et al., 2008; Jothityangkoon and Sivapalan, 2009; Cheng et al., 2011]. The Budyko framework assumes the steady state of water balance at long-term averages, i.e., $\Delta S=0$ in equation (1) [Donohue et al., 2007]; but at the annual scale, the effect of water storage change on the water balance generally needs to be taken into account [Zhang et al., 2008; Donohue et al., 2010]. However, because of the limitation of data availability on $E_{i}$ and $\Delta S_{i}$, the annual evaporation is usually computed on the basis of $E_{i}=P_{i}-Q_{i}$ by assuming the steady state condition, i.e., $\Delta S_{i}=0$ [e.g., Potter and Zhang, 2009; Yang et al., 2009]. It is necessary to examine the extent of which storage carryover affects the annual water balance using storage measurement data directly. To address this issue, this paper studies the interannual water storage change based on long-term soil moisture and groundwater level measurements in Illinois, and quantifies the impacts of storage change on the water balance at the mean annual and interannual scales. In section 2, the study watersheds and the corresponding data sets are introduced, and then the methods for estimating the storage change at the annual scale are described. The results and discussions are presented in sections 3 and 4, respectively. Conclusions are summarized in the section 5 .

\section{Data and Methods}

\subsection{Data Sets}

[7] Both soil moisture and groundwater level observation data were obtained from the Illinois State Water

Table 1. Twelve USGS Gauges and Corresponding Data ${ }^{\mathrm{a}}$

\begin{tabular}{|c|c|c|c|c|c|c|c|c|c|c|}
\hline \multirow[b]{2}{*}{ Index } & \multirow{2}{*}{$\begin{array}{c}\text { USGS } \\
\text { Gauge ID }\end{array}$} & \multirow{2}{*}{$\begin{array}{c}\text { Drainage } \\
\text { Area }\left(\mathrm{km}^{2}\right)\end{array}$} & \multirow[b]{2}{*}{$P(\mathrm{~mm})$} & \multirow[b]{2}{*}{$E_{p}(\mathrm{~mm})$} & \multirow[b]{2}{*}{$Q(\mathrm{~mm})$} & \multirow[b]{2}{*}{$E_{p} / P$} & \multirow[b]{2}{*}{$E / P$} & \multirow[b]{2}{*}{$Q_{s} / Q$} & \multicolumn{2}{|c|}{ Observations } \\
\hline & & & & & & & & & Soil Moisture & Ground Water \\
\hline 1 & 3345500 & 3926 & 1025 & 937 & 320 & 0.91 & 0.69 & 0.59 & 2 & 1 \\
\hline 2 & 3381500 & 8034 & 1091 & 1008 & 373 & 0.92 & 0.66 & 0.50 & 2 & 1 \\
\hline 3 & 5435500 & 3434 & 887 & 962 & 294 & 1.08 & 0.67 & 0.80 & 1 & 0 \\
\hline 4 & 5440000 & 2846 & 900 & 916 & 295 & 1.02 & 0.67 & 0.70 & 1 & 0 \\
\hline 5 & 5447500 & 2598 & 914 & 980 & 270 & 1.07 & 0.70 & 0.73 & 0 & 1 \\
\hline 7 & 5570000 & 4237 & 928 & 1009 & 281 & 1.09 & 0.70 & 0.63 & 1 & 0 \\
\hline 8 & 5584500 & 1696 & 966 & 995 & 268 & 1.03 & 0.72 & 0.49 & 0 & 1 \\
\hline 9 & 5585000 & 3349 & 965 & 992 & 267 & 1.03 & 0.72 & 0.51 & 0 & 0 \\
\hline 10 & 5592500 & 5025 & 1003 & 968 & 311 & 0.97 & 0.69 & 0.68 & 0 & 1 \\
\hline 11 & 5593000 & 7042 & 1007 & 991 & 290 & 0.98 & 0.71 & 0.73 & 1 & 1 \\
\hline 12 & 5594000 & 1904 & 1015 & 1018 & 289 & 1.00 & 0.72 & 0.46 & 0 & 0 \\
\hline
\end{tabular}

${ }^{\mathrm{a}}$ Mean annual precipitation $(P)$, potential evaporation $\left(E_{p}\right)$, streamflow $(Q)$, climate dryness index $\left(E_{p} / P\right)$, mean annual evaporation ratio $(E / P)$ where $E=P-Q$, the ratio of base flow to the total streamflow $\left(Q_{s} / Q\right)$, and the number of soil moisture and groundwater stations located in each watershed. 
Survey (ISWS). ISWS collected measurements of the soil moisture content at 19 locations throughout the state of Illinois as shown in Figure 1, beginning at most sites in 1981 and ending at some stations in 2004 [Scott et al., 2010]. The soil moisture content is measured for the top $10 \mathrm{~cm}$ and then for $20 \mathrm{~cm}$ layers down to a depth of $2 \mathrm{~m}$ (i.e., a total of 11 layers) with the neutron probe technique, calibrated with gravimetric observations [Hollinger and Isard, 1994]. The soil moisture is routinely observed on a biweekly basis during the growing season (March-October) and monthly thereafter. The vegetation at all stations is rural grass, except for one station with bare soil measurements. Figure 1B shows the land use and land cover map. The main land use is agricultural land, which includes rural grassland where the soil moisture is measured. This data set has been documented by Hollinger and Isard [1994] in detail, and is part of the Global Soil Moisture Data Bank [Robock et al., 2000].

[8] Since the 1960s, the Groundwater Division of ISWS has been collecting groundwater level data for shallow unconfined groundwater at 17 wells throughout the state of Illinois (Figure 1). All of the wells are far from streams or pumping wells [Changnon et al., 1988]. The groundwater level is measured on monthly intervals.

[9] The data availability of long-term observations of soil moisture and groundwater level in Illinois provides a unique opportunity to study the annual storage carryover at the watershed scale. The soil moisture data set has been used to study the water balance in the Illinois River basin [Niemann and Eltahir, 2004], to understand the characteristics of deep-layer hydrologic memory on surface energy fluxes [Атепи et al., 2005], and to simulate the water balance in the Illinois River basin [Yeh and Eltahir, 2005]. The combined soil moisture content and groundwater level data have been used to estimate the monthly evaporation [Yeh et al., 1998] and to validate the total water storage variation estimates from the Gravity Recovery and Climate Experiment (GRACE) satellite data [Swenson et al., 2006], both of which were done at the spatial scale of the entire state of Illinois. Recently, Yeh and Famiglietti [2009] applied the combined data sets to soil water balance computation for estimating the regional recharge to and evaporation from groundwater.

[10] The watersheds included in the international Model Parameter Estimation Experiment (MOPEX) data set, which includes the daily precipitation and streamflow data from 1948 to 2003 [Duan et al., 2006], are selected for the analysis considering the locations of soil moisture and groundwater level observation sites. The MOPEX data set has been used to study the functional model of water balance variability [Sivapalan et al., 2011] and the sensitivity of fast and slow runoff components to precipitation change [Harman et al., 2011]. Monthly potential evaporation, which is computed by the Priestley-Taylor method, is aggregated into annual values at the watershed scale [Priestley and Taylor, 1972; Zhang et al., 2010]. Twelve MOPEX watersheds, which cover or are close to soil moisture and groundwater measurement stations, were selected for the analysis in this study (panel A in Figure 1). The number of soil moisture and groundwater stations located in each watershed is shown in Table 1, which also shows the drainage area, mean annual precipitation, potential evaporation, streamflow, climate dryness index, mean annual evaporation ratio $(E / P)$, the ratio of base flow to the
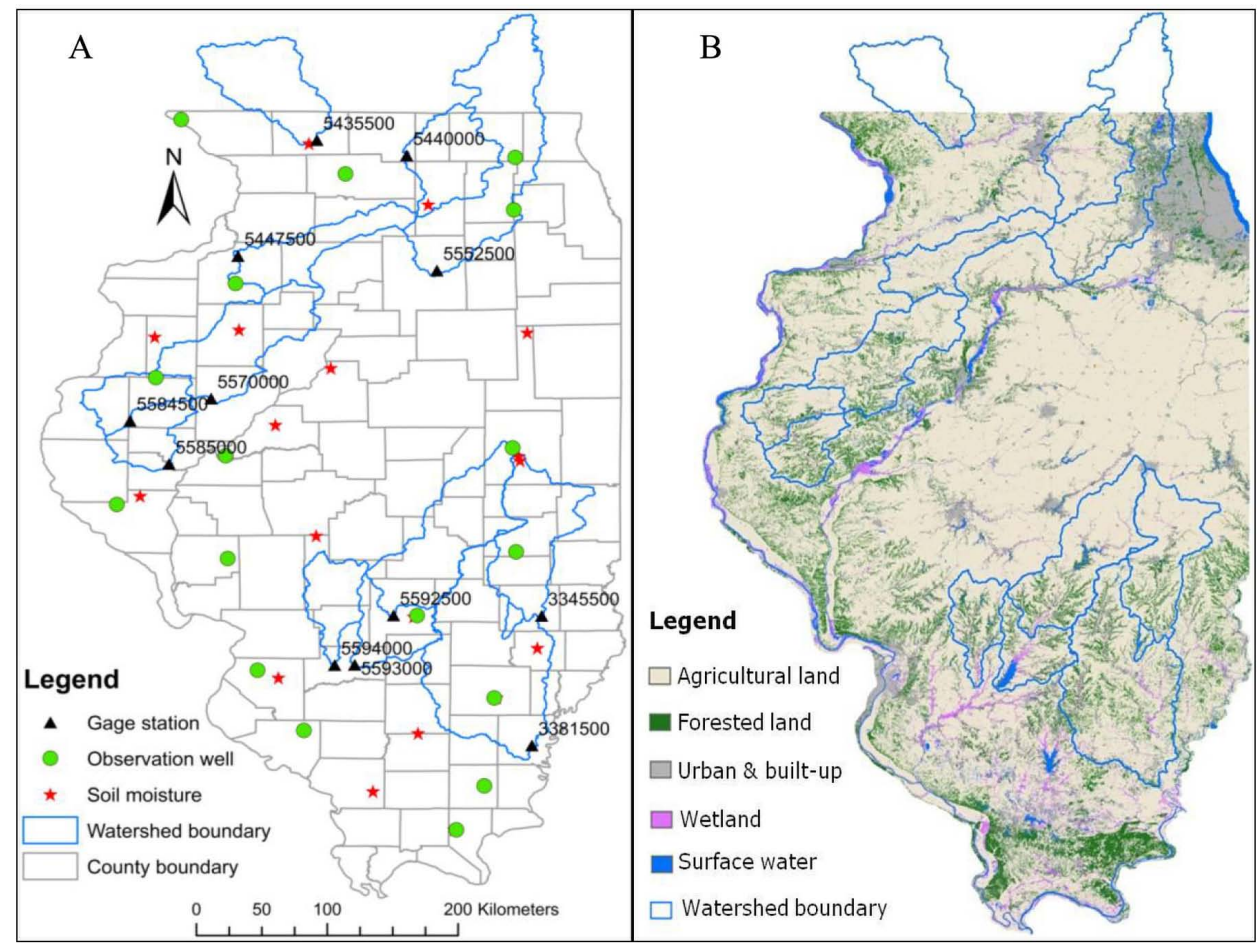

Figure 1. (a) Spatial distribution of USGS streamflow gauges of MOPEX data set, soil moisture measurement sites, and groundwater level observation wells (b) the land use and land cover. 
total streamflow, and the number of soil moisture and groundwater stations located in each watershed. The drainage area of the selected watersheds ranges from $1700 \mathrm{~km}^{2}$ to $8000 \mathrm{~km}^{2}$. In the 12 watersheds, the mean annual precipitation varies from $887 \mathrm{~mm}$ to $1091 \mathrm{~mm}$; the climate dryness index is in a small range from 0.91 to 1.08 ; and the mean annual evaporation ratio ranges from 0.66 to 0.72 .

\subsection{Estimation of Annual Storage Change}

[11] The total water storage change for a watershed at year $i$ includes three storage components:

$$
\Delta S_{i}=\Delta S_{s m, i}+\Delta S_{g w, i}+\Delta S_{s w, i}
$$

where $\Delta S_{s m, i}$ is soil moisture change; $\Delta S_{g w, i}$ is unconfined groundwater storage change; $\Delta S_{s w, i}$ is the surface water storage change such as snow pack and lakes. The confined aquifer storage change is assumed to be negligible or the interaction between the deep confined aquifer and the surface water is negligible. The water balance is accounted for based on water year, and the water storage change is computed based on the difference of storage in September from consecutive years. Since there is no snow storage in September in the state of Illinois and since surface water storage is small compared with the soil moisture and groundwater storage, $\Delta S_{s w, i}$ is assumed to be negligible [Yeh et al., 1998]. There is no significant reservoir or lake within the watersheds except the one draining to gauge station 5593000 (Figure 1B). Rodell and Famiglietti [2001] demonstrated that surface water storage variability in Illinois was, in nonflood years, at least an order of magnitude smaller than soil moisture and groundwater variability.

[12] The spatial distribution of soil moisture, groundwater level, and streamflow observations are shown in panel A of Figure 1. Based on the data availability, the annual storage change and its impact on interannual water balance are investigated during the water years from 1982 to 2003. There are two issues for estimating the annual carry-over of water storage using this data set: in some years and observation sites, soil moisture or/and groundwater table observation data are missing in September, which is the ending month of each water year; and there are no soil moisture and water table observations located within some watersheds (Figure 1 and Table 1). Therefore, the soil water content and groundwater level depth are interpolated spatially. In September of each year, a soil water content map and a groundwater level depth map are generated based on the inverse distance-weighted (IDW) method in ArcGIS. For demonstration purposes, Figure 2 shows the interpolated surfaces of groundwater depth (panel A) and soil water content (panel B) in September 1988. If observations located in a watershed are available, the original observation data is used to estimate the storage change. For a watershed in which there is no observation site or the measurement is not available in a month for the site located in the watershed, the interpolated field is used to compute the soil water content or groundwater level, i.e., the spatial average over the watershed. If a watershed is covered partially by the generated interpolation surface, the storages in uncovered areas are assumed to be same as the average values in the covered area. Therefore, the spatial interpolation is used to fill the missing data at spatial and/or temporal domains. As shown in Figure 1, both soil moisture and groundwater level observation sites are available within three watersheds (3345500, 3381500 , and 5593000); soil moisture observation sites are available within three watersheds $(5435500,5440000$, and 5570000); groundwater level observation sites are available within four watersheds $(5552500,5447500,5584500$, and $5592500)$; no observation site is available within two watersheds (5585000 and 5594000).

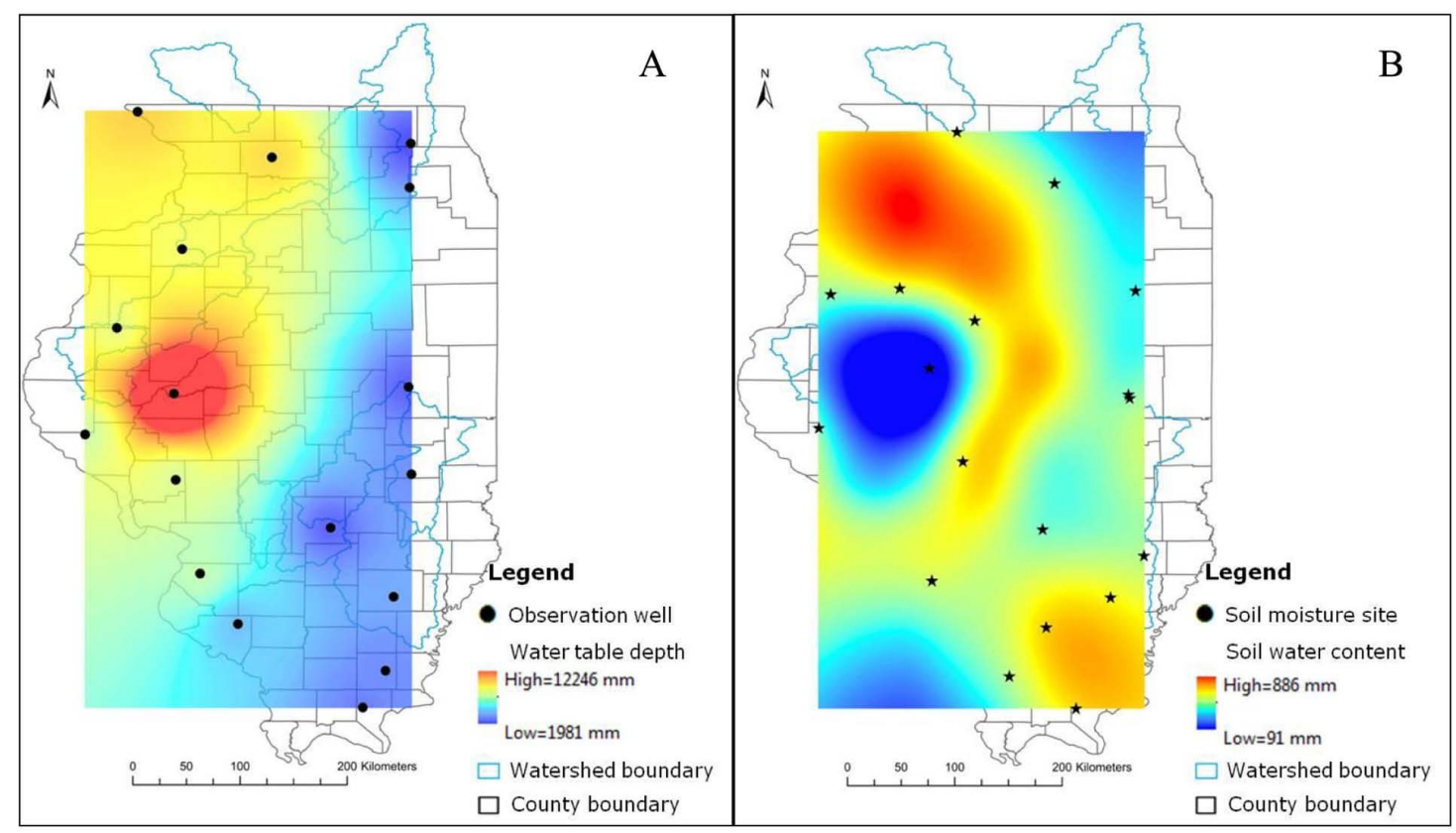

Figure 2. (a) Interpolated surface of groundwater table and (b) soil water content in September 1988 by inverse distance weighted (IDW) method. 
[13] The soil moisture storage change is computed by the difference of total soil water content at the top $2 \mathrm{~m}$ soil between two consecutive years. Changes in groundwater depth are converted to changes in groundwater storage by multiplying the specific yield which is in the range of 0.080.1 [Yeh et al., 1998]. To be conservative on the effect of storage change, a value of 0.08 is used in this paper so that the lower value of specific yield will result in less groundwater storage change estimation, which is the product of a water level change and specific yield. The water level in shallower wells can be $<2 \mathrm{~m}$ in depth, which implies that the soil moisture data may at times include water in both the root zone and the saturated zone. Following Swenson et al. [2006], to avoid the repetitive accounting of groundwater storage, if the water table depth is $<2 \mathrm{~m}$ deep, the water table depth is set to $2 \mathrm{~m}$ in the computation of groundwater storage change.

[14] The long-term average storage change can be computed from the annual storage changes:

$$
\Delta S=\frac{1}{N} \sum_{i=1}^{N} \Delta S_{i}
$$

where $N$ is the total number years for the long-term average. Generally, $\Delta S_{i}$ is positive in wet years and negative in dry years, and $\Delta S$ is negligible with a large enough value of $N$.

\subsection{Anomalies of Precipitation, Runoff, and Evaporation}

[15] The interannual variability of storage change responding to the variability of interannual precipitation is investigated. Subtracting equation (1) from equation (2), with negligible long-term mean annual storage change $(\Delta S)$ one obtains:

$$
\tilde{P}_{i}-\Delta S_{i}=\tilde{Q}_{i}+\tilde{E}_{i}
$$

where $\tilde{P}_{i}$ is the annual anomalous precipitation at the year $i$ and is defined as

$$
\tilde{P}_{i}=P_{i}-P
$$

Similarly, $\tilde{Q}_{i}$ and $\tilde{E}_{i}$ are the annual anomalous runoff and evaporation, respectively. The partitioning of mean annual precipitation can be characterized by the Budykotype curves. The effective precipitation anomaly, which is the difference from anomalous precipitation and storage change $\left(\tilde{P}_{i}-\Delta S_{i}\right)$, will be partitioned into runoff and evaporation anomalies at the annual scale. If the annual storage change is negligible, evaporation and runoff anomalies sum to the precipitation anomaly [Milly and Dunne, 2002]. The ratio of runoff anomaly to precipitation anomaly, $\tilde{Q} / \tilde{P}_{i}$, is usually called sensitivity of runoff to rainfall [Schaake, 1990; Dooge, 1992; Milly and Dunne, 2002; Harman et al., 2011].

\section{Results}

[16] The storage changes at two temporal scales are presented: mean annual and interannual storage carryover.
The responses of runoff, evaporation, and storage change variations to the climate variability are investigated based on the daily precipitation, potential evaporation, and streamflow data. To evaluate the impact of spatial interpolation (i.e., IDW) on the estimation of annual storage change, the obtained $\Delta S_{s m, i}$ and $\Delta S_{g w, i}$ from IDW and the original point-based observation are compared for the watersheds with observation sites when the measurement is available (Figure 3). For $\Delta S_{s m, i}$ (panel A), most data points are along the 1:1 line but the IDW-based estimation tends to overestimate the storage change compared with the point-based estimation. The bias is due to the spatial heterogeneity of soil moisture. For $\Delta S_{g w, i}$ (panel B), the IDW-based estimation matches the original point-based observation very well for most data points. The IDW-based estimation of $\Delta S_{g w, i}$ tends to underestimate the storage change compared with the point-based estimation. Comparing the soil water storage change and groundwater storage change from the point-based observation, the groundwater component has a greater storage capacity than the soil component; $\Delta S_{s m, i}$ and $\Delta S_{g w, i}$ are comparable but the groundwater storage has
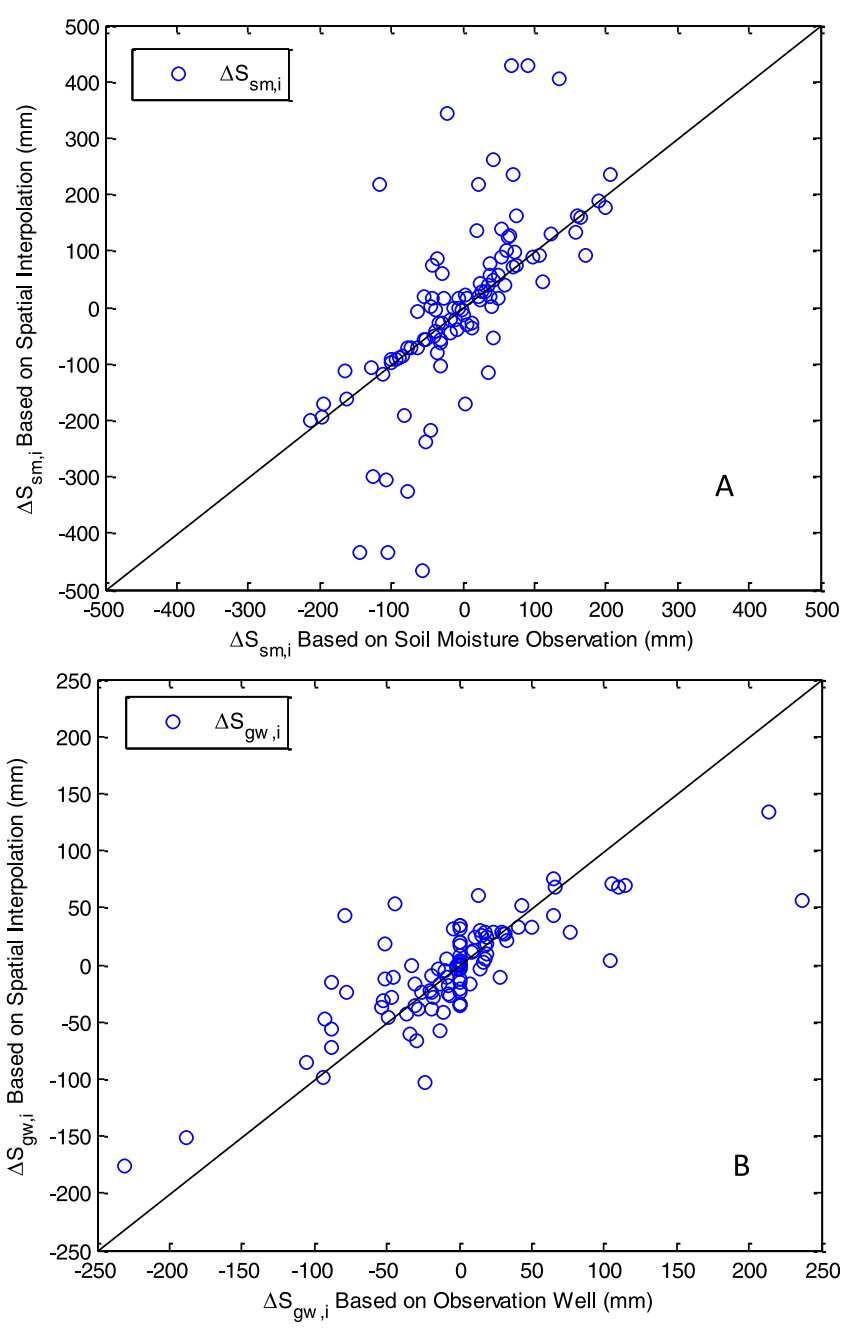

Figure 3. (a) Comparison of annual soil water storage change and (b) annual groundwater storage change from point-based observation and the spatially based average through interpolation by the inverse distance weighted (IDW) method. 
higher lower and upper bounds (i.e., $\sim 250 \mathrm{~mm}$ for $\Delta S_{g w, i}$ and $200 \mathrm{~mm}$ for $\left.\Delta S_{s m, i}\right)$. As shown in Table 1, the ratio of base flow to the total streamflow $\left(Q_{s} / Q\right)$ during the 22-yr period is higher than 0.50 , except for two watersheds with values of 0.49 and 0.46 , and the highest $Q_{s} / Q$ value is 0.80 in watershed 5435500 .

\subsection{Mean Annual Storage Change $\Delta S$}

[17] Figure 4 shows the ratio of average annual storage change to mean annual precipitation, $\Delta S / P$, for each watershed. Among the 12 watersheds, the minimum value of $\Delta S / P$ is $-2.6 \%$, the maximum value is $1.4 \%$, and the average value of $|\Delta S / P|$ is $0.9 \%$. In this study, the value of $N$ is 22 , and the storage change is considerably small compared with the mean annual rainfall; thus, if $N$ is large enough (e.g., $N>30 \mathrm{yr}$ ), $\Delta S$ is indeed negligible.

\subsection{Annual Storage Change}

\subsubsection{Annual Soil Moisture Storage Change Versus Annual Groundwater Storage Change}

[18] The storage change includes two components in the study watersheds: soil water storage change and groundwater storage change. Lo et al. [2010] studied the estimated GRACE total water storage anomalies against the observed water table depth averaged over Illinois for the period of 2003-2005 and found the correlation coefficient between total water storage anomalies and water table depth to be 0.87 . Thus, the total storage change and the groundwater level fluctuation is highly positively correlated. Figure 5 plots the annual soil moisture storage change versus the annual groundwater storage change from all 12 watersheds (the data points are excluded when the water table depth is lower than $2 \mathrm{~m}$ ). The correlation coefficient between $\Delta S_{s m, i}$ and $\Delta S_{g w, i}$ is 0.4 . The lower bound of the storage change of soil moisture is around $-200 \mathrm{~mm}$ except five points, which are due to interpolation errors as shown in Figure 3. Groundwater storage changes are in the range between $-300 \mathrm{~mm}$ and $300 \mathrm{~mm}$.

\subsubsection{Annual Total Water Storage Change}

[19] The estimated annual total water storage changes are presented in section 3.2.2. The histogram of the annual storage change ratio, which is defined as the ratio of annual storage change $\left(\Delta S_{i}\right)$ to annual precipitation $P_{i}$, from all 12 watersheds in all of the years is shown in Figure 6 . The mode of the distribution is approximately of zero value of

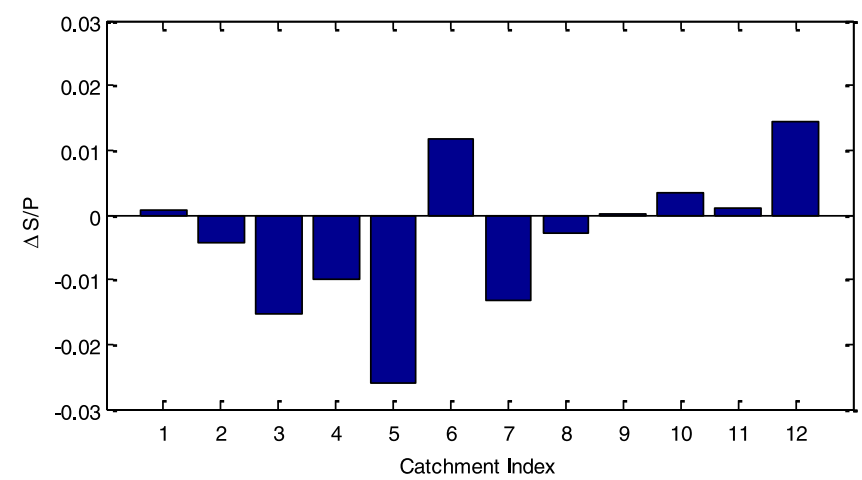

Figure 4. Ratio of mean annual storage change to mean annual precipitation $(\Delta S / P)$. The catchment indexes correspond to the indexing in Table 1.

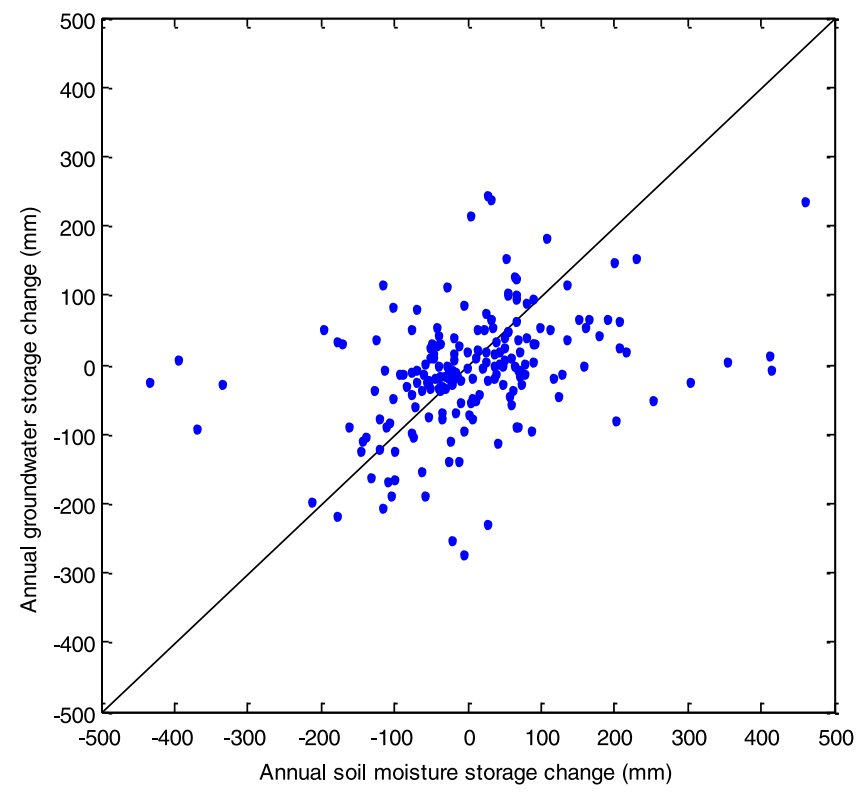

Figure 5. Annual soil moisture storage change $\left(\Delta S_{s m, i}\right)$ versus annual groundwater storage change $\left(\Delta S_{g w, i}\right)$.

annual storage change ratio. The distribution has a longer and thicker tail of negative valued $\Delta S_{i} / P_{i}$. Excluding the points in the outliers from spatial interpolation, the minimum and maximum annual storage change ratios are $-60 \%$ and $40 \%$, respectively. Figure 7 shows the exceedance probability distribution of the absolute values of annual storage change ratios for all of the watersheds in all years. Values of $\left|\Delta S_{i} / P_{i}\right|$ are larger than $10 \%$ during $40 \%$ of the years and larger than $5 \%$ during $70 \%$ of the years. Therefore, neglecting interannual storage carryover during wet or dry years can be problematic in the watersheds of study.

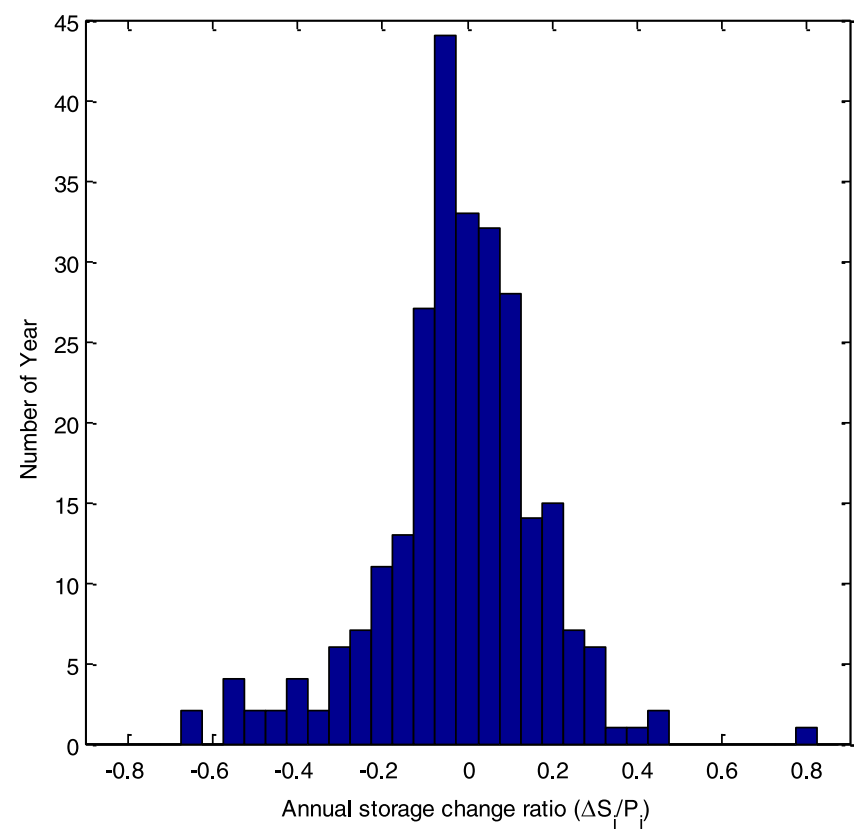

Figure 6. Histogram of annual storage change ratio $\Delta S_{i} / P_{i}$. 


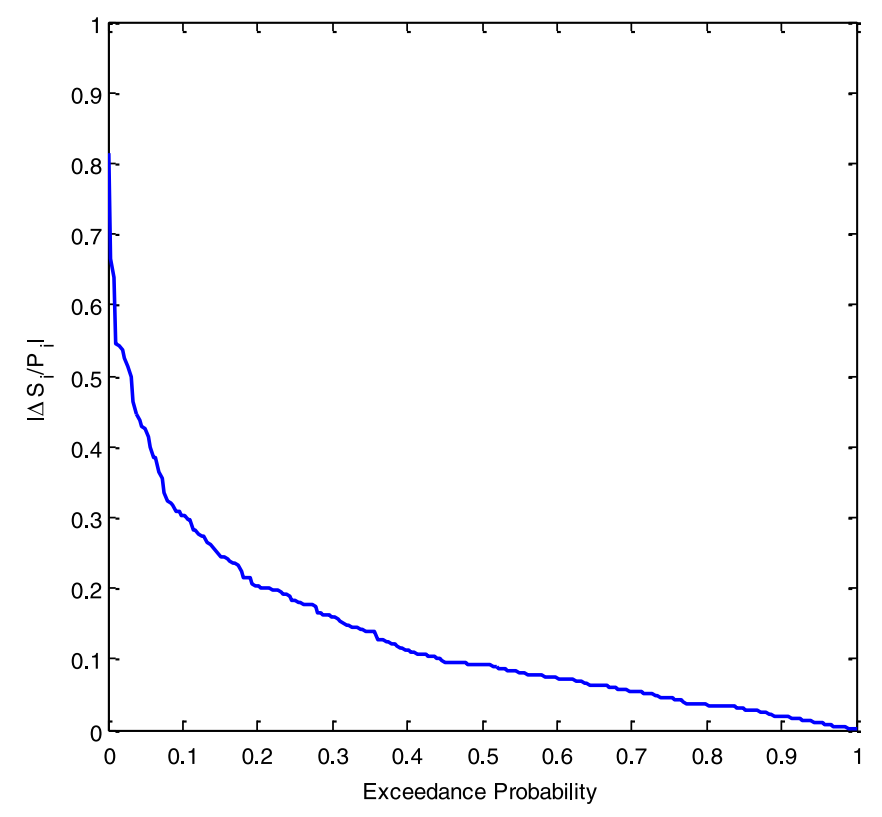

Figure 7. Exceedance probability of absolute values of annual storage change ratios.

\subsubsection{Response of Annual Storage Change to Annual Precipitation Variability}

[20] In order to compare the annual anomalies between watersheds, the annual precipitation anomaly ratio is defined as $\left|\tilde{P}_{i} / P\right|$, where $P$ is the mean annual precipitation for the corresponding watershed. The annual storage change ratio $\left(\Delta S_{i} / P\right)$ versus the annual precipitation anomaly ratio from all of the watersheds is shown in panel $A$ in Figure 8 . The correlation coefficient between $\Delta S_{i} / P$ and $\tilde{P}_{i} / P$ is 0.42 . According to the Budyko curve, the sensitivity of runoff to rainfall change is closer to 1 under energylimited conditions, but closer to 0 under water-limited conditions [Koster and Suarez, 1999]. The study watersheds are located in the equivalent climate region where $E_{p} / P$ is $\sim 1.0$. The correlation coefficient between $\tilde{Q}_{i} / P$ versus $\tilde{P}_{i} / P$ is high, up to 0.73 as shown in panel $\mathrm{B}$; but the annual evaporation anomaly ratio $\tilde{E}_{i} / P$ and $\tilde{P}_{i} / P$ are poorly correlated, with a coefficient of 0.02 (panel $\mathrm{C}$ ). The annual evaporation anomaly ratio $\tilde{E}_{i} / P_{\tilde{P}}$ versus the annual effective precipitation anomaly ratio, $\left(\tilde{P}_{i}-\Delta S_{i}\right) / P$, has a correlation coefficient of 0.71 as shown in panel B. Therefore, the interannual variability of evaporation is not strongly correlated with the interannual variability of precipitation, but is correlated with the interannual variations of effective precipitation. This suggests that the interannual variability of evaporation in the study watersheds is mainly dependent on precipitation anomaly and the annual storage carryover.
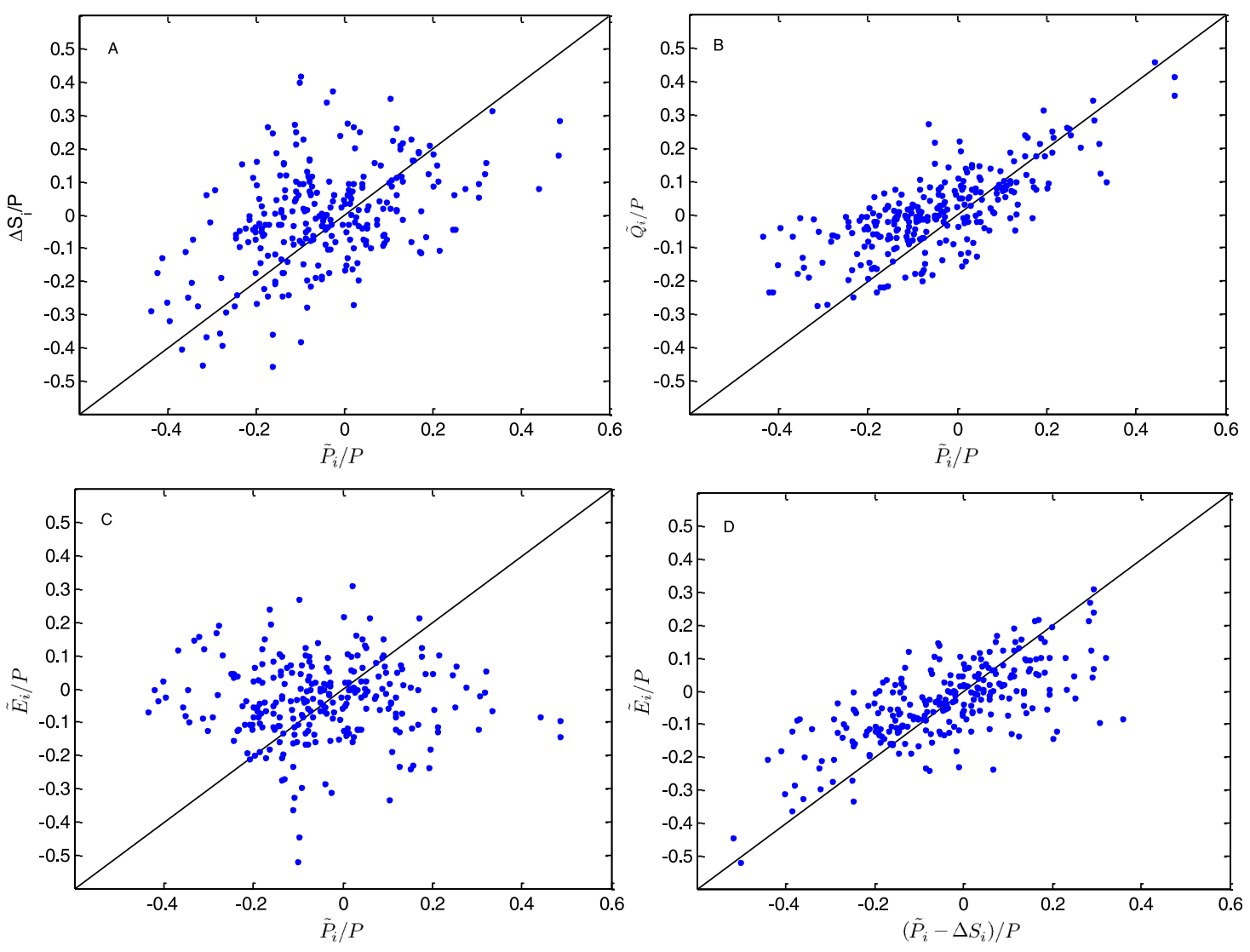

Figure 8. (a) Annual storage change ratio, (b) annual runoff anomaly ratio, (c) annual evaporation anomaly ratio versus annual effective precipitation anomaly ratio, and (d) annual evaporation anomaly ratio versus annual effective rainfall anomaly ratio. 

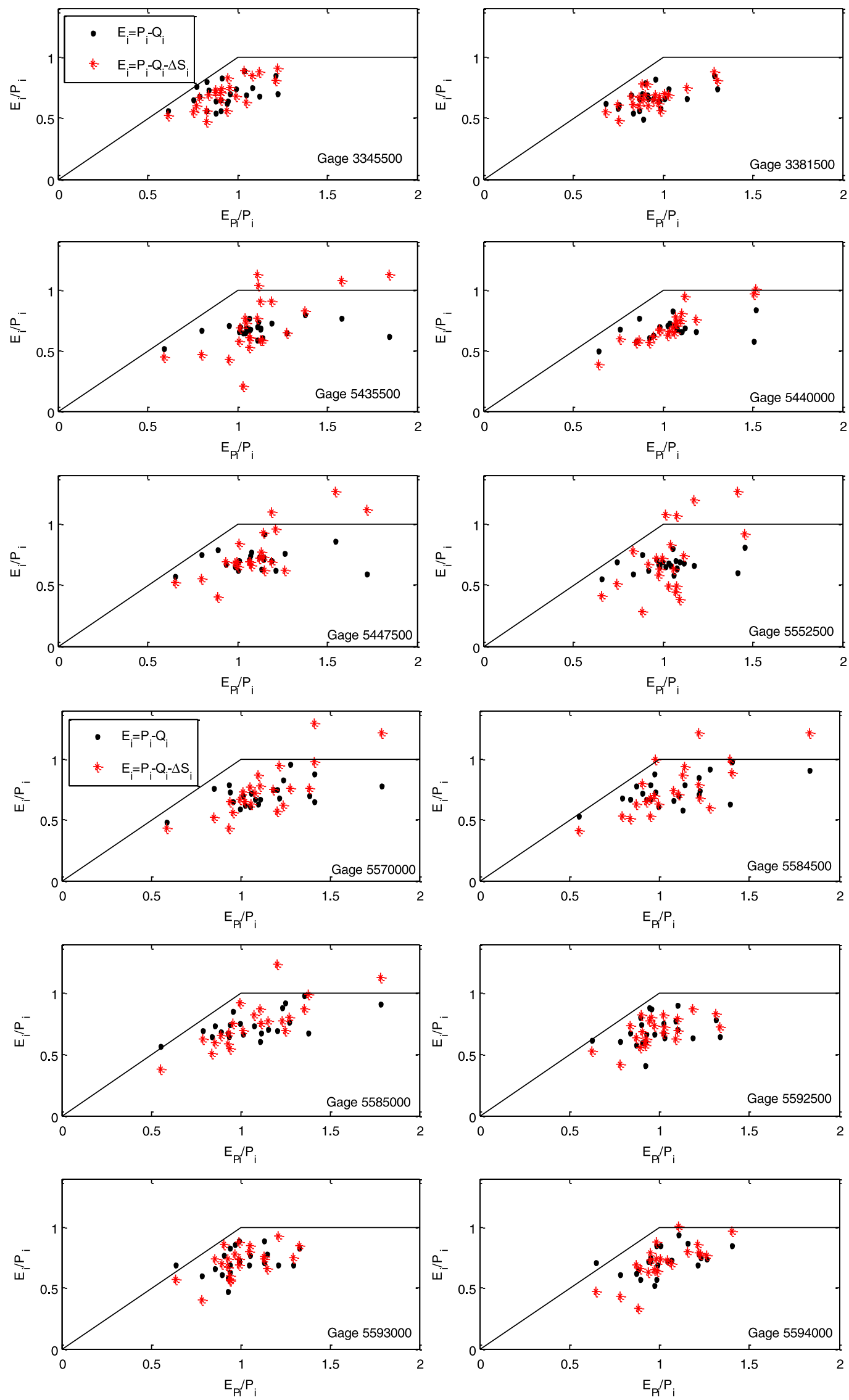

Figure 9. Annual $E_{i} / P_{i}$ versus $E_{p i} / P_{i}$ for each watershed during 1982-2003. 


\section{Discussions}

\subsection{Annual Storage Change Effects in the Budyko Framework}

[21] Figure 9 shows annual $E_{i} / P_{i}$ versus $E_{p i} / P_{i}$ in the Budyko framework for all 12 watersheds with the annual evaporation estimated by two water balance methods: first, the annual storage change is assumed to be negligible, i.e., $E_{i}=P_{i}-Q_{i}$; and second, the annual storage change estimated from the soil moisture and groundwater level observation is used to estimate the annual evaporation, i.e., $E_{i}=$ $P_{i}-Q_{i}-\Delta S_{i}$. The evaporation data of black dots are from the first method assuming $\Delta S_{i}=0$, and the evaporation data of red stars is adjusted by the estimated annual storage change. Because of the effects of annual water storage carryover, the data points tend to move upward for large values of dryness indexes but move downward for small values of dryness indexes as compared with the case ignoring annual carryover. Especially for very high values of dryness index (for example, watershed 5435500 in Figure 9), the evaporation can exceed precipitation because the water storage is utilized for the water supply during dry years. As shown in Figure 1B, the main land use in the study watersheds is agricultural land and the human activities such as urbanization are minimum. Therefore, the groundwater pumping, if it exists, is mainly for irrigation. Under these circumstances, the total supply of water includes both precipitation and soil water storage. For example, one data point, which is the year 1988 , is located above the line of $E_{i} / P_{i}=1$ for watershed 5435500 . The values of $E_{i} / P_{i}$ and $E_{p i} / P_{i}$ are 1.1 and 1.7, respectively, and the soil moisture change is $-105 \mathrm{~mm}$, and the groundwater storage change is $-188 \mathrm{~mm}$. For watershed 5447500 , the values of $E_{i} / P_{i}$ and $E_{p i} / P_{i}$ in 1988 are 1.1 and 1.6, respectively, and the soil moisture change is $-117 \mathrm{~mm}$, and the groundwater storage change is $-205 \mathrm{~mm}$, where the groundwater storage change is twice of soil moisture storage change. Extreme drought occurred during 1988 in North America, which included Illinois [Trenberth et al., 1988; Lamb, 1992]. During this drought year, annual evaporation exceeded the annual precipitation. Watersheds with $E_{i}>P_{i}$ have been reported in Australia and India [Talsma and Gardner, 1986; Calder et al., 1997], and the water use by Eucalyptus species is greater than rainfall input during dry years.

[22] As shown in Figure 9, compared with data points assuming $\Delta S_{i}=0$, the scattering of data points considering storage carryover is stretched along the vertical direction. This makes the data points behave more linearly even though some data points behave more nonlinearly. Cheng et al. [2011] analyzed the relationship between annual evaporation ratio and potential evaporation ratio over 500 watersheds in the United States and found that a strong linear relationship exists, and they discussed the controlling factors on the linear relationship such as climate, soil water storage, vegetation, and human activities. Figure 10 shows the correlation coefficients between annual and potential evaporation ratio for all 12 watersheds under the two methods of evaporation estimation. The effect of annual water storage change increases the correlation coefficient between annual $E_{i} / P_{i}$ and $E_{p i} / P_{i}$. As shown in Table 1, the mean annual climate of the study watersheds is located in

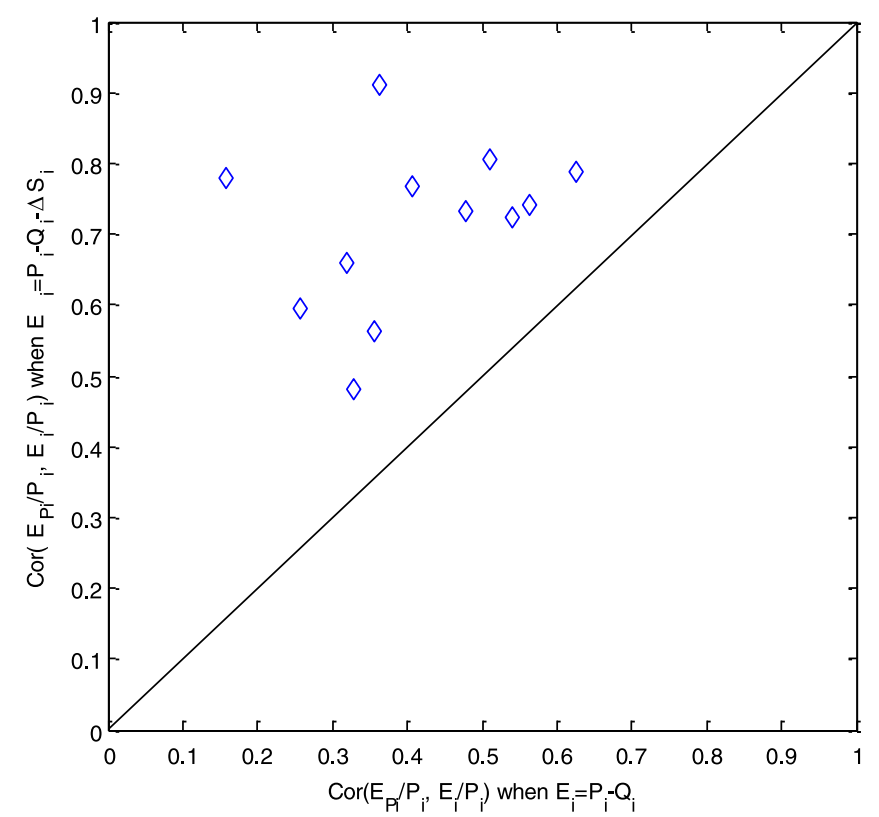

Figure 10. Correlation coefficients between annual evaporation ratio and potential evaporation ratio for each watershed from two methods of estimating annual evaporation: assuming annual storage change is negligible, and annual storage change estimated from soil moisture and groundwater level observations.

the transition from energy-limited region to water-limited region. In dry years, the water limitation effect is mitigated by the water supply through soil water storage. Therefore, the data points in dry years continue the trend of being located in the energy-limited region instead of becoming flat which is represented in the Budyko curve.

[23] In the Budyko framework, the dryness index is the ratio between the supply of energy and the supply of water, and the evaporation ratio is the ratio between the evaporation and the supply of water. It is reasonable that precipitation is used to represent the total water supply under steady state conditions and when no lateral water flow occurs. Other sources of water supply, if they exist, should be included in the denominators of the climate dryness index and evaporation ratio. For irrigated watersheds in arid regions, Han et al. [2011] took the sum of annual precipitation and irrigation water withdrawal as the total water supply under the Budyko framework. Under nonsteady state conditions water supply is also affected by natural water storage changes and the supply of water beyond just precipitation. Therefore, total water supply can be represented by effective precipitation $\left(P_{i}-\Delta S_{i}\right)$. Correspondingly, the evaporation ratio and climate dryness index in the Budyko framework can be calculated by $E_{i} /\left(P_{i}-\Delta S_{i}\right)$ and $E_{P_{i}} /\left(P_{i}-\right.$ $\left.\Delta S_{i}\right)$, respectively. Figure 11 shows the annual evaporation ratio and dryness index using effective precipitation for each watershed. It is intriguing that the red dots in Figure 9 are move back into a more Budyko-like distribution.

\subsection{Uncertainty in Storage Change Estimation}

[24] The uncertainty of the storage change estimation should be recognized. The spatial variability of soil moisture under a seemingly uniform condition increases with 

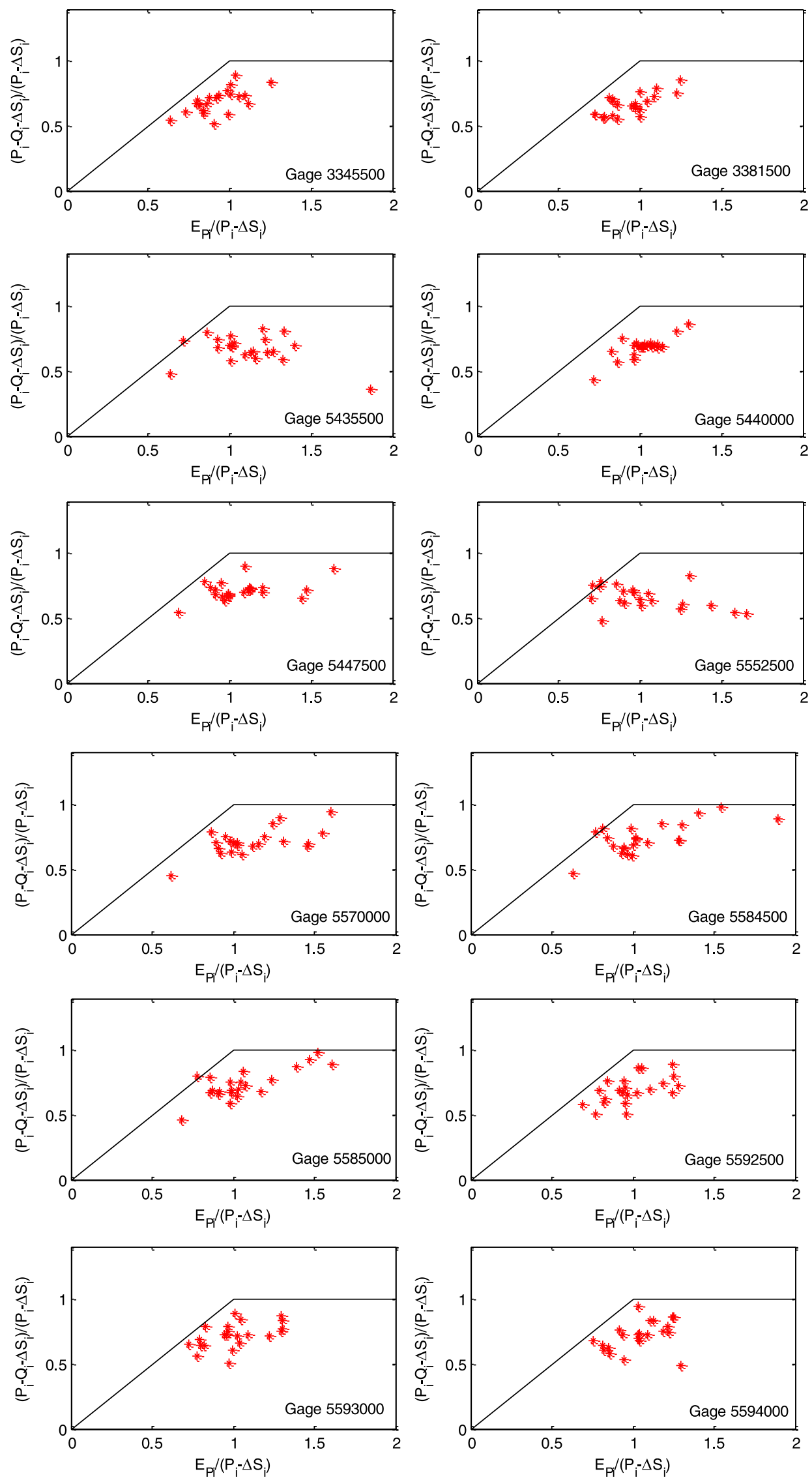

Figure 11. Annual $E_{i} /\left(P_{i}-\Delta S_{i}\right)$ versus $E_{p i} /\left(P_{i}-\Delta S_{i}\right)$ for each watershed during 1982-2003. 
depth, and the average standard deviation of all temporal observations is $2.26 \%$ in the top $30 \mathrm{~cm}$ of soil and $5.19 \%$ in the 170-200 cm layer [Scott et al., 2010]. The long-term observations of volumetric soil moisture were conducted under land cover of rural grassland and most of Illinois is under an agricultural cover. There are five major factors affecting the accuracy of the estimated watershed water storage. First, the in situ soil moisture observations contain measurement errors, due to the imperfect relationship between the calibrated neutron probe response and the true soil moisture content, and the uncertainty of the volumetric soil moisture made in Illinois to be $\sim 5 \%-10 \%$ [Hollinger and Isard, 1994]. This uncertainty effects may be cancelled out on the change of watershed water storage. Second, consideration of the interpolation of soil moisture and the water table depth in the spatial coverage of the watersheds. Third, the soil moisture is measured on a bi-weekly basis, and the soil moisture measurement at the end of September (usually during approximately 26-29 September) is used for computing the interannual soil moisture storage change. Soil moisture, especially at the top layers, may vary significantly during the measurement period. Fourth, a constant value of groundwater specific yield is used (i.e., 0.08) based on the literature. Fifth, consider that spatial interpolation of soil moisture and groundwater level when pointbased observation is not available.

\section{Summary and Conclusions}

[25] This paper aims to examine the extent to which water storage carryover affects the annual water balance. The interannual variability of soil water storage changes at the watershed scale is quantified directly using the longterm observations of soil moisture and groundwater level data in Illinois. The approach is applied to a total of 12 watersheds on the basis of the available data sets. The mean annual storage change is indeed negligible in the mean annual water balance, since the mean annual storage change ratios $(\Delta S / P)$ vary from $-2.6 \%$ to $1.4 \%$ and the average of absolute value is $0.9 \%$ at the study watersheds. However, the interannual variability of storage change can be a significant component in annual water balance during dry and wet years, since the annual storage change ratios $\left(\Delta S_{i} / P_{i}\right)$ vary from $-60 \%$ to $40 \%$ in the study watersheds where the interannual soil water and groundwater storage changes are comparable.

[26] The effect of soil water capacity decreases the sensitivity of annual evaporation to the interannual variability of precipitation. The partitioning of the annual precipitation anomaly into annual streamflow and evaporation anomalies is buffered by the interannual storage change. The correlation coefficients of the annual precipitation anomaly ratio versus the annual runoff anomaly ratio, annual storage change ratio, and annual evaporation anomaly ratio are $0.73,0.42$, and 0.02 , respectively. The annual evaporation anomaly ratio is positively correlated with the annual effective precipitation anomaly ratio and the correlation coefficient is 0.71 . If soil water storage changes were ignored, the interannual variability of storage change would be counted in the evaporation variations, and the interannual variability of evaporation would be overestimated considerably.

[27] Because of the effects of annual water storage carryover, the data points in the Budyko framework move upward for large values of dryness indexes but move downward for small values of dryness indexes as compared with the case ignoring annual carryover. Groundwater storage plays a more significant role, relative to soil moisture storage, on the annual water balance in drought years. For very high values of dryness index, the evaporation ratios can exceed the water limit due to the buffering of water storage capacity, especially groundwater storage. The effect of the annual water storage change increases the correlation coefficient between the annual evaporation ratio and the annual potential evaporation ratio.

[28] These analyses, in conjunction with those of Flerchinger and Cooley [2000], Milly and Dunne [2002], Zhang et al. [2008], Leblanc et al. [2009], Oishi et al. [2010], and Donohue et al. [2010], demonstrate that storage change at an annual timescale may need to be considered unless steady state conditions can be explicitly demonstrated in study watersheds. Under nonsteady state conditions, water storage changes need to be included in the estimation of evaporation and total water supply. Effective precipitation can be used as a substitute for precipitation when computing evaporation ratio and climate dryness index.

[29] Acknowledgments. Partial financial support for the author was provided by the Walter and Betty Boardman Foundation at University of Central Florida. The author would like to thank the Illinois State Water Survey for providing the soil moisture and groundwater level data. The author is also very grateful to the associate editor and three anonymous reviewers for their insightful and constructive feedback on this manuscript.

\section{References}

Amenu, G. G., P. Kumar, and X.-Z. Liang (2005), Interannual variability of deep-layer hydrologic memory and mechanisms of its influence on surface energy fluxes, J. Clim., 18, 5024-5045.

Budyko, M. I. (1958), The heat balance of the Earth's surface (translated from Russian by N. A. Stepanova), 259 pp., U.S. Dep. of Commer., Washington, D.C.

Budyko, M. I. (1974), Climate and Life, 508 pp., Academic, N. Y.

Calder, I. R., P. T. W. Rosier, K. T. Prasanna, and S. Parameswarappa (1997), Eucalyptus water use greater than rainfall input-a possible explanation from southern India, Hydrol. Earth Syst. Sci., 1(2), 249-256.

Changnon, S. A., F. A. Huff, and C. F. Hsu (1988), Relations between precipitation and shallow groundwater in Illinois, J. Clim., 1, 1239-1250.

Cheng, L., Z. Xu, D. Wang, and X. Cai (2011), Assessing interannual variability of evapotranspiration at the catchment scale using satellitebased evapotranspiration data sets, Water Resour. Res., 47, W09509, doi:10.1029/2011WR010636.

Choudhury, B. J. (1999), Evaluation of an empirical equation for annual evaporation using field observations and results from a biophysical model, J. Hydrol., 216, 99-110.

Donohue, R. J., M. L. Roderick, and T. R. McVicar (2007), On the importance of including vegetation dynamics in Budyko's hydrological model, Hydrol. Earth Syst. Sci., 11, 983-995.

Donohue, R. J., M. L. Roderick, and T. R. McVicar (2010), Can dynamic vegetation information improve the accuracy of Budyko's hydrological model?, J. Hydrol., 390(1-2), 23-34.

Dooge, J. (1992), Sensitivity of runoff to climate change: A Hortonian approach, Bull. Am. Meteorol. Soc., 73, 2013-2013.

Duan, Q., et al. (2006), The model parameter estimation experiment (MOPEX): An overview of science strategy and major results from the second and third workshops, J. Hydrol., 320, 3-17, doi:10.1016/ j.jhydrol.2005.07.031.

Flerchinger, G. N., and K. R. Cooley (2000), A ten-year water balance of a mountainous semi-arid catchment, J. Hydrol., 237, 86-99.

$\mathrm{Fu}$, B. P. (1981), On the calculation of the evaporation from land surface (in Chinese), Sci. Atmos. Sin., 5(1), 23-31.

Gerrits, A. M. J., H. H. G. Savenije, E. J. M. Veling, and L. Pfister (2009), Analytical derivation of the Budyko curve based on rainfall characteristics and a simple evaporation model, Water Resour. Res., 45, W04403, doi:10.1029/2008WR007308. 
Han, S., H. Hu, D. Yang, and Q. Liu (2011), Irrigation impact on annual water balance of the oases in Tarim Basin, Northwest China, Hydrol. Processes, 25, 167-174.

Harman, C. J., P. A. Troch, and M. Sivapalan (2011), Functional model of water balance variability at the catchment scale: 2 . Elasticity of fast and slow runoff components to precipitation change in the continental United States, Water Resour. Res., 47, W02523, doi:10.1029/2010WR009656.

Hickel, K., and L. Zhang (2006), Estimating the impact of rainfall seasonality on mean annual water balance using a top-down approach, J. Hydrol., $331,409-424$.

Hollinger, S. E., and S. A. Isard (1994), A soil moisture climatology of Illinois, J. Clim., 7, 822-833.

Jothityangkoon, C., and M. Sivapalan (2009), Framework for exploration of climatic and landscape controls on catchment water balance, with emphasis on inter-annual variability, J. Hydrol., 371, 154-168.

Koster, R. D., and M. J. Suarez (1999), A simple framework for examining the interannual variability of land surface moisture Fluxes, J. Clim., 12, 1911-1917.

Lamb, P. J. (Ed.) (1992), The 1988-1989 drought in Illinois: Causes, dimensions, and impacts, Res. Rep. 121, 154 pp., Ill. State Water Surv., Champaign.

Leblanc, M. J., P. Tregoning, G. Ramillien, S. O. Tweed, and A. Fakes (2009), Basin-scale, integrated observations of the early 21 st century multiyear drought in southeast Australia, Water Resour. Res., 45, W04408, doi:10.1029/2008WR007333.

Lo, M.-H., J. S. Famiglietti, P. J.-F. Yeh, and T. H. Syed (2010), Improving parameter estimation and water table depth simulation in a land surface model using GRACE water storage and estimated base flow data, Water Resour. Res., 46, W05517, doi:10.1029/2009WR007855.

Milly, P. C. D. (1994a), Climate, interseasonal storage of soil-water, and the annual water-balance, Adv. Water Resour., 17(1-2), 1-24.

Milly, P. C. D. (1994b), Climate, soil water storage, and the average annual water balance, Water Resour. Res., 30, 2143-2156.

Milly, P. C. D., and K. A. Dunne (2002), Macroscale water fluxes, 2. Water and energy supply control of their interannual variability, Water Resour. Res., 38(10), 1206, doi:10.1029/2001WR000760.

Niemann, J. D., and E. A. B. Eltahir (2004), Prediction of regional water balance components based on climate, soil, and vegetation parameters, with application to the Illinois River Basin, Water Resour. Res., 40, W03103, doi:10.1029/2003WR002806.

Oishi, A. C., R. Oren, K. A. Novick, S. Palmroth, and G. G. Ka (2010), Interannual invariability of forest evapotranspiration and its consequence to water flow downstream, Ecosystems, 13, 421-436.

Ol'dekop, E. M. (1911), On evaporation from the surface of river basins (in Russion), Trans. Meteorol. Observ., 4, 200.

Oudin, L., V. Andréassian, J. Lerat, and C. Michel (2008), Has land cover a significant impact on mean annual streamflow? An international assessment using catchments, J. Hydrol., 357, 303-316.

Pike, J. G. (1964), The estimation of annual runoff from meteorological data in a tropical climate, J. Hydrol., 2, 116-123.

Porporato, A., E. Daly, and I. Rodriguez-Iturbe (2004), Soil water balance and ecosystem response to climate change, Am. Nat., 164(5), 625-632.

Potter, N. J., and L. Zhang (2009), Interannual variability of catchment water balance in Australia, J. Hydrol., 369, 120-129.

Potter, N. J., L. Zhang, P. C. D. Milly, T. A. McMahon, and A. J. Jakeman (2005), Effects of rainfall seasonality and soil moisture capacity on mean annual water balance for Australian catchments, Water Resour. Res., 41, W06007, doi:10.1029/2004WR003697.

Priestley, C. H. B., and R. J. Taylor (1972), On the assessment of surface heat flux and evaporation using large-scale parameters, Mon. Weather Rev., 100, 81-92.

Robock, A., Y. V. Konstantin, G. Srinivasan, J. K. Entin, S. E. Hollinger, N. A. Speranskaya, S. Liu, and A. Namkhai (2000), The global soil moisture data bank, Bull. Am. Meteorol. Soc., 81, 1281-1299.

Rodell, M., and J. S. Famiglietti (2001), An analysis of terrestrial water storage variations in Illinois with implications for the gravity recovery and climate experiment (GRACE), Water Resour. Res., 37, 1327-1340.

Sankarasubramanian, A., and R. V. Vogel (2002), Annual hydroclimatology of the United States, Water Resour. Res., 38(6), 1083, doi:10.1029/ 2001WR000619.
Schaake, J. C. (1990), From climate to flow, in Climate Change and U.S. Water Resources (edited by P. E. Waggoner), chapt. 8, pp. 177-206, John Wiley, N.Y.

Schreiber, P. (1904), Über die Beziehungen zwischen dem Niederschlag und der Wasserführung der Flüsse in Mitteleuropa, Meteorologische Zeitschrift, 21(10), 441-452.

Scott, R. W., E. C. Krug, and S. L. Burch (2010), Illinois soil moisture under sod experiment, J. Hydrometeor., 11, 683-704, doi:10.1175/ 2009JHM1130.1

Sivapalan, M., M. A. Yaeger, C. J. Harman, X. Xu, and P. A. Troch (2011) Functional model of water balance variability at the catchment scale: 1 . Evidence of hydrologic similarity and space-time symmetry, Water Resour. Res., 47, W02522, doi:10.1029/2010WR009568.

Swenson, S., P. J.-F. Yeh, J. Wahr, and J. Famiglietti (2006), A comparison of terrestrial water storage variations from GRACE with in situ measurements from Illinois, Geophys. Res. Lett., 33, L16401, doi:10.1029/ 2006GL026962.

Talsma, T., and E. A. Gardner (1986), Soil-water extraction by a mixed eucalypt forest during a drought period, Aust. J. Soil Res., 24(1), 25-32.

Trenberth, K. E., G. W. Branstator, and P. A. Arkin (1988), Origins of the 1988 North American Drought, Science, 424(4886), 1640-1645.

Wang D., and M. Hejazi (2011), Quantifying the relative contribution of the climate and direct human impacts on mean annual streamflow in the contiguous United States, Water Resour. Res., 47, W00J12, doi:10.1029/ 2010WR010283.

Wang, T., E. Istanbulluoglu, J. Lenters, and D. Scott (2009), On the role of groundwater and soil texture in the regional water balance: An investigation of the Nebraska Sand Hills, USA, Water Resour. Res., 45, W10413, doi:10.1029/2009WR007733.

Yang, D., F. Sun, Z. Liu, Z. Cong, G. Ni, and Z. Lei (2007), Analyzing spatial and temporal variability of annual water-energy balance in nonhumid regions of China using the Budyko hypothesis, Water Resour. Res., 43, W04426, doi:10.1029/2006WR005224.

Yang, D., W. Shao, P. J. F. Yeh, H. Yang, S. Kanae, and T. Oki (2009), Impact of vegetation coverage on regional water balance in the nonhumid regions of China, Water Resour. Res., 45, W00A14, doi:10.1029/ 2008WR006948

Yang, H., D. Yang, Z. Lei, and F. Sun (2008), New analytical derivation of the mean annual water-energy balance equation, Water Resour. Res., 44, W03410, doi:10.1029/2007WR006135.

Yeh, P. J.-F., and E. A. B. Eltahir (2005), Representation of water table dynamics in a land surface scheme, Part I: Model development, J. Clim., $18,1861-1880$

Yeh, P. J.-F. and J. S. Famiglietti (2009), Regional groundwater evapotranspiration in Illinois, J. Hydrometeor., 10(4), 464-478, doi:10.1175/ 2008JHM1018.1.

Yeh, P. J.-F., M. Irizarry, and E. A. B. Eltahir (1998), Hydroclimatology of Illinois: A comparison of monthly evaporation estimates based on atmospheric water balance with estimates based on soil water balances, J. Geophys. Res., 103(D16), 19:823-19:837.

Yokoo, Y., M. Sivapalan, and T. Oki (2008), Investigating the roles of climate seasonality and landscape characteristics on mean annual and monthly water balances, J. Hydrol., 357, 255-269.

Zhang, K., J. S. Kimball, R. R. Nemani, and S. W. Running (2010), A continuous satellite-derived global record of land surface evapotranspiration from 1983-2006, Water Resour. Res., 46, W09522, doi:10.1029/ 2009WR008800

Zhang, L., W. R. Dawes, and G. R. Walker (2001), Response of mean annual evapotranspiration to vegetation changes at catchment scale, Water Resour. Res., 37(3), 701-708.

Zhang, L., N. Potter, K. Hickel, Y. Zhang, and Q. Shao (2008), Water balance modeling over variable time scales based on the Budyko framework-model development and testing, J. Hydrol., 360, 117-131.

D. Wang, Department of Civil, Environmental, and Construction Engineering, University of Central Florida, 4000 Central Florida Blvd., PO Box 162450, Orlando, FL 32816, USA. (dingbao.wang@ucf.edu) 